\title{
Journal of Bacteriology and

\section{Prevalence of Gastro-Intestinal Parasitic Infection among School Children in Port Harcourt City Local Government Area, Nigeria}

\section{Emmanuel I Michael ${ }^{*}$, Austin Abah and Peace Marcus}

Department of Microbiology, Institute of Science Laboratory Technology, University of Port Harcourt PMB, 5323, Choba, Rivers State, Nigeria

*Corresponding author: Emmanuel I Michael, Department of Microbiology, Institute of Science Laboratory Technology, University of Port Harcourt PMB, 5323, Choba, Rivers State, Nigeria, E-mail: emmanuelmichael001@yahoo.com

Received date: September 11, 2017; Accepted date: October 07, 2017; Published date: October 13, 2017

Copyright: (C) 2017 Michael El, et al. This is an open-access article distributed under the terms of the creative commons attribution license, which permits unrestricted use, distribution, and reproduction in any medium, provided the original author and source are credited.

\begin{abstract}
Intestinal parasitic infection is a serious and continuous health issue in Nigeria due to the suboptimal nature of sanitary equipment and housing facilities. Knowing the prevalence of intestinal parasitic infection among primary school pupils is a very vital concern to develop appropriate control measure in Port Harcourt City Local Government Area of Rivers State (PHALGA). A total of 250 children were examined. A study to determine the prevalence of intestinal parasitic infection was conducted. A Structured questionnaire was used to establish environmental, behavioral and sociodemographic factors of the pupils. Stool samples were collected from all study subjects into sterile sample bottles and examined for parasites using a direct smear and formol-ether concentration technique. The results were analyzed statistically using GraphPad prism version 7 statistical tool. A total of $24.8 \%$ (62 of 250 children) carried on intestinal parasite. The most prevalent intestinal parasites identified were Ascaris lumbricoides $(12.4 \%)$, Trichuris trichiura $(6.8 \%)$ and hookworm $(5.6 \%)$. This study indicated that the prevalence of intestinal parasites is associated with drinking unprotected well/spring water and less educated parents who do not practice hand washing before meal. Therefore, interventions such as chemotherapy, provision of adequate sanitary facilities and portable drinking water, improved personal hygiene and health education should be considered and implemented. Thus, these segments of the population should be considered by governmental and nongovernmental health institutes for any community-based intervention program.
\end{abstract}

Keywords: Intestinal parasites; Prevalence; Helminthes; Public health; Infection; Gastrointestinal

\section{Introduction}

Intestinal parasitic infection caused by helminthes and protozoan are serious public health problems in developing countries [1-3].

Parasites that affect the gastro-intestinal tracts are among the most common infections worldwide. It is estimated that 3.5 billion people are affected, and 450 million are ill as a result of these infections, the majority of whom are children [4].

Parasites are one of the most common causative agents of diarrhea, weight loss, abdominal pain, nausea, vomiting, lack of appetite, abdominal distention and iron deficiency anemia [5].

Unavailability of clean and safe drinking water, highly populated density, inappropriate disposal of waste, noncompliance with health standards, lack of adequate washing of food substances (vegetables and fruits), and consumption of improperly cooked meat lead to high prevalence of intestinal parasites [6,7].

The present study therefore sought to ascertain the prevalence of gastrointestinal parasites among Primary school pupils in Port Harcourt City local government area of Nigeria.

\section{Materials and Methods}

\section{Study area}

The study was conducted in Port Harcourt, the capital city of Rivers State. Port Harcourt is located between latitudes of $04^{\circ} 4^{\prime} \mathrm{N}$ and longitudes $07^{\circ} 10^{\prime} \mathrm{E}$ at the southern region of Nigeria in West Africa. Port Harcourt enjoys a tropical monsoon climate characterized by high temperature, low pressure and high humidity all year round. It has a mean temperature of $30^{\circ} \mathrm{C}\left(86^{\circ} \mathrm{F}\right)$ and a relative humidity of between $80 \%$ and $100 \%$ and a mean annual rainfall of $2,300 \mathrm{~mm}$ [8].

\section{Data collection and study population}

The study examined stool samples of Primary school children. Data collection and variations in distribution patterns of positive stool samples between sex and age consistency of the stool sample (formed, soft, semi-soft and watery) were recorded for identification and comparison of infection rate based on sample appearance. GraphPad prism version 7 statistical tool was used to compare relative frequencies between groups (sex and age). $\mathrm{P}$ value $<0.05$ were considered statistically significant. Questionnaires were given to every child that was sampled to ascertain socio demographic characteristics such as toilet system, method of waste disposal, source of drinking water, residential settlements, parent's level of education and how often they deworm their children.

Survey questionnaire of gastrointestinal parasites and risk factors Child's \# Date:

1. Parent/guardian signature 
Page 2 of 4

(Informed Consent)

2. Age of child:

3. Gender of child:

4.

Place

of

Community/

Birth$$
7 .
$$$$
\text { Country }
$$$$
\text { City }
$$$$
\text { of }
$$

8. Number of years living in your present residence:

9. Other cities or countries where the child has lived before current place residence

$$
10 .
$$

Parent's

level

education

11. What is the total number of people living in your household?

12. Circle any of the following symptoms that the child has had in the last 7 days:

(a) Diarrhea (b) Blood in stools (c) Abdominal pain (d) Nausea (e) Worms in stools (f) Anal itching (g) Fever (h) Vomiting (i) Abdominal distention (j) Loss of appetite (k) Increased appetite (l) Weight loss (m) Weight gain (n) Headache (o) Rash (p) Dry cough without a cold or chronic cough (q) Coughing up worms (r) Greasy stools

13. Has the child ever been diagnosed in a clinic or hospital with a parasite or worm of the intestines or stomach? (a) No (b) Yes...if so, (i) When?

What kind?

No (c) Unsure

14. Has the child recently been given medicine in school for parasites? (a) Yes....if so, (i) When?

No (c) Unsure

15. How many times a year does the child visit a clinic or hospital?

16. Where do you get your drinking water? (a) Purchase bottled water (b) Community well (c) Tap water

(d) River or stream (e) Rain water collected Other

17. If you do NOT buy bottled water, what do you treat your water with before drinking? (a) Nothing (b) Boil (c) Iodine (d) Chlorine (e) Filter...if so, (i) What Other (g) Unsure
18. What type of toilet do you use at home or where do you use the bathroom? (a) Indoor flushable toilet (b) Public or shared outdoor latrine (c) Private outdoor latrine (d) Outside/ Nature (e) Other

19. What type of toilet does the child use at school? (a) Indoor flushable toilet (b) Outdoor latrine (c) Other - (d) Unsure

20. How often does the child wash his/her hands with soap and water after using the toilet? (a) Never (b) Sometimes (c) Rarely (d) Always

21. Does the child use any of the following after a bowel movement to clean himself/herself? (a) Toilet paper (b) Cloth (c) Paper (d) Stones (e) Leaves (f) Nothing (g) Other

22. How often does the child wash his/her hands with soap and water before eating? (a) Never (b) Sometimes (c) Rarely (d) Always

23. What kinds of animals live in or around your house? (a) Dog (b) Cat (c) Pig (d) None (e) Cow (f) Horse (g) Chicken (h) Goat (i) Sheep (j) Donkey (k) Other

24. What type of floor is in your home? (a) Dirt (b) Tile (c) Cement (d) Other

\section{Analysis of Stool Samples/Identification of Intestinal Parasites}

About $1 \mathrm{~g}$ portion of the preserved stool sample was analyzed by the formol-ether concentration method as described by [9]. About $1 \mathrm{~g}$ of the faeces was emulsified in $4 \mathrm{ml}$ of $10 \%$ formol water and mix properly. Microscopic slides were made as studied in a light microscope at $100 \times$ and $400 \times$ magnifications for the presence of cysts and ova of the parasites.

Samples collection and processing was carried out on the same day. A drop of physiological saline was placed on a clean grease-free slide. A little quantity of thoroughly mixed stool sample was collected with the aid of an applicator stick and emulsified on the drop of the saline. The emulsified sample was covered with a cover slip and light microscopy at100x and finally with 400x magnifications for microscopic examination. Formol-ether concentration technique was employed. One milliliter of a thoroughly-mixed stool sample was put in a tube containing $4 \mathrm{~mL}$ of $10 \%$ formalin. Three milliliters of the $10 \%$ formalin was introduced and mixed by shaking. Separation of the suspension was aided by a coffee strainer into a tube of centrifuge. Three milliliters of diethyl ether was added and stoppered. It was then shaken vigorously for $1 \mathrm{~min}$. The stopper was removed and the suspension centrifuged for $1 \mathrm{~min}$ at $400 \mathrm{rpm}$. The complete division of the liquid below the fecal remains and ether was carefully removed using a Pasteur pipette and transferred into another tube of centrifuge. Ten percent formalin was to the transferred suspension to make up to $10 \mathrm{~mL}$. It was then centrifuged at $1000 \mathrm{rpm}$ for $10 \mathrm{mins}$. The supernatant was decanted and the bottom of the tube tapped to resuspend the deposit. The deposit was examined by light microscopy at 100x and 400x magnifications for the presence of ova or cyst of parasites. 
Page 3 of 4

\section{Results}

A total of 250 children aged 1-11 years participated in the study; $112(44.8 \%)$ and $138(55.2 \%)$ were females and males respectively. Total infected indicated $27(10.8 \%)$ and not infected 223(89.2\%) out of 250 examined. Parasites identified in the study were Ascaris lumbricoides 10(4.0\%), 21(8.4\%), Trichuris trichiura 9(3.6\%), 8(3.2\%) and Hook worm $8(3.2 \%), 6(2.4 \%)$ for males and females respectively (Table 1$)$.

\begin{tabular}{|l|l|l|}
\hline Intestinal Parasites & Males & Females \\
\hline Ascaris lumbricoides & $10(4.0 \%)$ & $21(8.4 \%)$ \\
\hline Trichuris trichuira & $9(3.6 \%)$ & $8(3.2 \%)$ \\
\hline Hookworm & $8(3.2 \%)$ & $6(2.4 \%)$ \\
\hline
\end{tabular}

Table 1: Percentage distribution of intestinal parasitic infection among school children in Port Harcourt City Local Government Area.

Indicate the frequency and types of parasites with gender distribution (Figure 1). Female pupils were more infected than males. Analysis of stool sample across gender appearance indicated $37(14.8 \%), 78(31.2 \%), 52(20.8 \%)$ and $83(33.2 \%)$ as formed, soft, semisoft and watery respectively (Table 2 ). Anthropometric data obtained explained the risk factors for intestinal parasitic infection. Result obtained from 250 children indicated that 138(55.2\%) females and $112(44.8 \%)$ males had their drink source of water from tap water, stream water and well water in the trend as follows; stream 59(23.6\%), tap 29(11.6\%), well 50(20.0\%) for females and tap 53(21.2\%), stream $39(15.6 \%)$ and $20(8.0 \%)$ for males (Table 3). Deworming in the last 6 months of study showed that $119(47.6 \%)$ females had no treatment, followed by $19(7.6 \%)$ with treatment. Males treated $46(18.4 \%)$ had treatment, but 66(26.4\%) were never treated. Routine hand washing after toilet use appeared to be a very significant risk factor with $116(46.4 \%), 78(31.2 \%), 22(8.80 \%)$ and $34(13.6 \%)$ that practiced and do not practice for both females and males respectively. Co-infection with mixed species of parasites among the 62(24.8\%) infected out of 250 subjects were $11(4.4 \%)$ females and 6(2.4\%) (Table 4$)$.

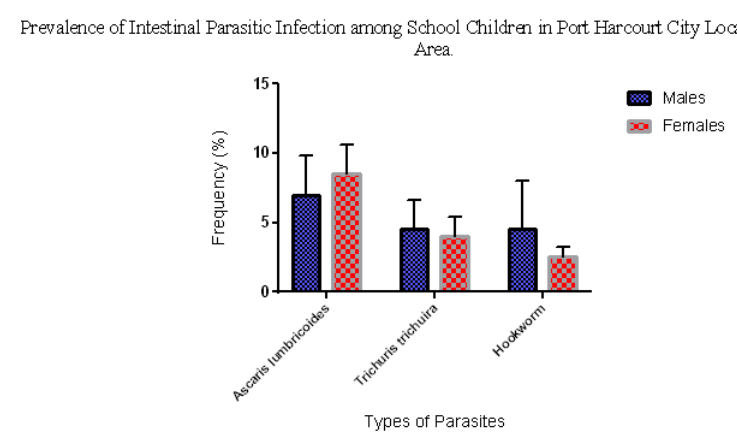

Figure 1: Statistical analysis of frequency and types of parasites.

\section{Factors associated with intestinal parasite infection}

The statistical analysis showed that significant factors related to the occurrence of intestinal parasite infections were unavailability of safe water supply, exposure to moist soil during outdoor games and educational grade had statistical significant association with the occurrence of intestinal parasitic infection $(\mathrm{P}<0.05)$.

\begin{tabular}{|l|l|}
\hline Stool Sample Appearance & $\%$ Frequency \\
\hline Formed & $37(14.8)$ \\
\hline Soft & $8(3.2 \%)$ \\
\hline Semi-soft & $52(20.8 \%)$ \\
\hline Watery & $83(33.2 \%)$ \\
\hline
\end{tabular}

Table 2: Stool sample analysis.

\begin{tabular}{|l|l|l|}
\hline Drinking Water Source & $\begin{array}{l}\text { Females } \\
\mathbf{( 5 5 . 2 \% )}\end{array}$ & Males 112 (44.8\%) \\
\hline Tap water & $29(11.6 \%)$ & $53(21.2 \%)$ \\
\hline Stream water & $59(23.6 \%)$ & $39(15.6 \%)$ \\
\hline Well water & $50(20.0 \%)$ & $20(8.0 \%)$ \\
\hline Deworm (Last 6 months) & & \\
\hline Yes & $19(7.6 \%)$ & $46(18.4 \%)$ \\
\hline No & $119(47.6 \%)$ & $66(26.4 \%)$ \\
\hline Hand Wash (After Toilet Use) & & $78(31.2 \%)$ \\
\hline Yes & $116(46.4 \%)$ & $34(13.6 \%)$ \\
\hline No & $22(8.80 \%)$ & \\
\hline
\end{tabular}

Table 3: Survey risk factors associated with intestinal parasites.

\begin{tabular}{|l|l|l|}
\hline Co-Infection & Females & Males \\
\hline \%Frequency & $11(4.4 \%)$ & $6(2.4 \%)$ \\
\hline Total Subjected & $112(44.8 \%)$ & $138(55.2 \%)$ \\
\hline
\end{tabular}

Table 4: Co-infection with mixed species of parasites.

\section{Discussion}

The present study showed that primary school pupils in Port Harcourt City Local Government Area (PHALGA) were infected with intestinal parasite to a non-trivial extent. The present study was similar to a previous study in Nigeria [10], on the prevalence of intestinal helminthes and protozoan parasites. In this study, the observed overall prevalence rate of intestinal parasite which is somewhat lower than previously reported among different regions in Port Harcourt. Epidemiological survey by [11], on intestinal helminthiasis in the Akpor area of Port Harcourt, Rivers State, recorded $42.7 \%$ prevalence of hookworm 16.0\%, Ascaris lumbricoides 15.4\%, Trichuris trichiura $8.0 \%$, Strongyloides stercoralis $3.0 \%$, and Taenia saginata $1.7 \%$. This high prevalence could be due to the standard of living of the subjects and the geographical condition of the study area. This study found that intestinal helminthes remain a problem in Port Harcourt. The prevalent species were Ascaris lumbricoides (12.4\%), Trichuris trichiura (6.8\%) and hookworm (5.6\%), are prevalent among primary school children in Port Harcourt city Local Government Area. Previous research attributes transmission of these parasites to be due to the sanity level of environmental as many children are exposed to moist soil during outdoor activities such as games. Similarly, the high prevalence observed in our study likely to be associated with poor 
Citation: Michael El, Abah A, Marcus P (2017) Prevalence of Gastro-Intestinal Parasitic Infection among School Children in Port Harcourt City Local Government Area, Nigeria. J Bacteriol Parasitol 8: 323. doi:10.4172/2155-9597.1000323

Page 4 of 4

hygienic conditions and status of health education among parents of the sampled population in Port Harcourt City Local Government Area. High prevalence of intestinal parasitic infection has been reported to occur in this geographical settlement $[11,12]$. The parasitic infection recorded by this study therefore synchronizes with an overall high prevalence of gastrointestinal tract infections in this study area due to the level of sanitation and economic status of the inhabitants.

\section{Ethical Considerations}

Communication with the administrators of schools sampled was made through formal letter obtained from Port Harcourt Local Government Education Authority. In order to keep confidentiality of any information provided by study subjects, the data collection procedure was anonymous.

\section{Acknowledgement}

The authors are thankful to the Department of Animal and Environmental Biology, University of Port Harcourt, Primary school administrators and Port Harcourt Local Government Education Authority for assisting us achieve this task.

\section{References}

1. Lwambo NJ, Siza JE, Brooker S, Bundy DA, Guyatt H (1999) Patterns of concurrent hookworm infection and schistosomiasis in school children in Tanzania. Trans R Soc Trop Med Hyg 93: 497-502.

2. Handzel T, Karanja DM, Addiss DG, Hightower AW, Rosen DH, et al. (2003) Geographic distribution of schistosomiasis and soiltransmitted helminths in Western Kenya: Implication for anthelminthic mass treatment. Am J Trop Med Hyg 69: 318323.

3. Bethony J, Chen J, Lin S, Xiao S, Zhan B, et al. (2002) Emerging patterns of hookworm infection: Influence of aging on the intensity of Necator infection in Hainan Province, People's Republic of China. Clin Infect Dis 35: 13361344 .

4. World Health Organization WHO (1998) Control of tropical diseases, WHO, Geneva, Switzerland.

5. Workneh T, Esmael A, Ayichiluhm M (2014) Prevalence of intestinal parasitic infections and associated factors among Debre Elias Primary Schools Children, East Gojjam Zone, Amhara Region, North West Ethiopia. J Bacteriol Parasitol 5: 181.

6. Damen JG, Banwat EB, Egah DZ, Allanana JA (2007) Parasitic contamination of vegetables in Jos, Nigeria. Ann Afr Med 6: 115-118.

7. Soleimnanpoor H, Zohor A, Ebrahimzadeh A, Biranvand L, Dabirzadeh M (2013) The survey of parasitic contamination of vegetables in Zabol city during 2011-2012. Zabol Uni Med Sci 3: 40-47.

8. Mmom PC (2003) The Niger Delta: A Spatial perspective to its development. Port Harcourt: Zelon Enterprises.

9. World Health Organization WHO (1994) Bench aids for the diagnosis of intestinal parasites, WHO, Geneva, Switzerland.

10. Ozumba UC, Ozumba N (2002) Patterns of helminth infection in the human gut at the University of Nigeria Teaching Hospital, Enugu, Nigeria. J Health Sci 48: 263268.

11. Abah AE, Arene FOI (2006) Intestinal parasitic infections among primary school children as an index of level of sanitation in Akpor Area of Port Harcourt, Rivers State Nigeria. Nig Soc Parasitol.

12. Awi-waadu GDB (2005) The prevalence of gastro-intestinal tract parasites in the inhabitants of Bori military cantonment in Port Harcourt Local Goverment Area of Rivers State, Nigeria. Afr J Appl Zool Environ Bio 7: 56-60. 